\author{
MAGDA, M. ABD- EL RAHMAN. *
}

\begin{abstract}
Adequate storage may reduce subsequent losses. Adequate storage involves proper regulation of temperature, humidity, air circulation, proper stacking pattern, regular inspection, and prompt produce disposal as soon as maximum storage life has been attained. One of the greatest impediments to preserving quality through refrigerated storage is the consumers' strong preference for freshly harvested produce and resistance to stored produce. This research aims to test the feasibility of improving the performance of cold storage rooms by using the evaporative cooler to control air relative humidity inside the storage. Some operating parameters such as, water flow rate of pad surface, $(0.075,0.120,0.165$ and $0.210 \mathrm{~m} 3 / \mathrm{h})$ and pads face air velocity $(0.25$, 0.50 and $0.75 \mathrm{~m} / \mathrm{s}$ ) on the air temperature, and air relative humidity inside storage room were studied. The effect of such process on the performance of cold storage rooms in terms of tomatoes fruits storageability (weight loss percentage) and fruits firmness were also considered. The results revealed that, optimum values for the operations conditions were obtained at $0.165 \mathrm{m3} / \mathrm{h}$ of water flow rates of pad and 0.5 $\mathrm{m} / \mathrm{s}$ of pad-face air velocity. The maximum deteriorated of tomatoes stored with evaporative cooler was (5.62\%), comparing with the deteriorated value of the control treatment (14.69\%). Tomatoes stored without evaporator cooler (control treatment) gave the lowest firmness (48.66 N), which was coupled with maximum total damage (14.69\%).
\end{abstract}

\title{
INTRODOUCTION
}

Dhroughout the period between harvest and consumption, temperature control has been found to be the most important

factor in maintaining product quality. Fruits and vegetables are living, respiring tissues separated from their parent plant. Keeping products at their lowest safe temperature will increase storage life by

* Senior Researcher, Agric. Eng. Res. Inst. (AEnRI), Giza. 
lowering respiration rate, decreasing sensitivity to ethylene gas and reducing water loss. Reducing the rate of water loss slows the rate of shriveling and wilting, cause of serious post harvest losses. Another aspect to consider when handling fruits and vegetables is the relative humidity of the storage environment. Loss of water from produce is often associated with a loss of quality, as visual changes such as wilting or shriveling and textural changes can take place.

In Egypt there are hundreds of refrigerated storages used for short or long-term storage of fruits and vegetables. Storage are used as a marketing tool to smooth out peaks and valleys in production, allow a more continuous supply to customers, and help maintain the quality of produce. Storages come in a vast array of sizes, layouts and construction methods, all of which are critical to their proper function. For fresh market produce, any method of increasing the relative humidity of the storage environment will slow the rate of water loss. The method of increasing relative is to add moisture to the air around the commodity at last, resort, by wetting the store room floor.

Wilson et al. (1995), Janet and Richard (2000), and Lisa and Kader (2004), reported that the relative humidity in refrigerated storage must be within the optimum range for the commodity. For most fruits and vegetables, the optimum relative humidity is $85-90$ percent. When relative humidity inside the refrigerated storage is less than 85 percent, the facility should use a humidifier. The air to coil temperature differential of the refrigeration unit must be no greater than $50{ }^{\circ} \mathrm{F}$. The temperature differential equals the difference between the temperature of the refrigerant entering the coil and the temperature of the air in the refrigerated facility. Air to coil temperature differentials greater than $50^{\circ} \mathrm{F}$ condenses water vapor in the air, reducing relative humidity in the facility and producing ice accumulations on the evaporator coils. When the humidity is lower, air tends to absorb water from the stored produce, causing it to wilt. The addition of moisture to the facility by dumping water on the floor is a common practice to add moisture to the air. Whereas, James (1996), and Byczynski (1997) showed that forced air cooling causes virtually no moisture loss under some conditions. In other cases, losses are great enough to damage the product and prevent the use 
of this cooling method. Amount of moisture loss depends on: initial temperature of the product, product transpiration coefficient, use of waxes or moisture resistant packaging, and humidity of the cooling air. Maintaining high relative humidity in storage is complicated by the fact that refrigeration removes moisture. They added that humidification devices such as spinning disc aspirators may be used. Even buckets of water will increase humidity as the fans blow air across the water's surface and increase evaporation.

Tassou and Xiang (1998) reported that the relative humidity and temperature of the air are important parameters in cold store design and operation. Relative humidity is the ratio of the partial presser of water vapour in the air to the partial pressure at saturation at the same temperature. Since it is the water vapour pressure difference between the store air and the surface of the produce that drives the transpiration process, to minimize weight loss it is important to maintain the store air at as high a value of relative humidity as possible, typically $90 \% \mathrm{RH}$. Although, Geeson, (1989) showed that low temperatures and high humidity's can be achieved in a cold store by using either forced air cooling with conventional coils or, forced air cooling with wet cooling system. The latter system provides much higher cooling rates than the conventional system and is thus used for rapid cooling and short term holding of fruits and vegetables.

Many authors reported and described the evaporation cooling system, Wang (1993) ASHRAE (1998), ASAE (2000), Campos et al. (2002), CEC (2006), USDE (2009), and Wikipedia (2009), showed that evaporative coolers (also called swamp, desert, or air coolers) are devices that cool air through the simple evaporation of water. The evaporation cooling systems are based on the process of heat absorption during the evaporation of water. There are two types of evaporation cooling systems, misting or fogging system and fan-bad cooling system. These systems are normally evaluated in terms of an evaporative cooling or saturation efficiency. On other words, evaporation cooling is an air conditioning process that uses the evaporation of liquid water to cool an air stream directly or indirectly so that the final dry bulb or dry and wet bulb temperatures of the air stream were being cooled. 
Factors affecting the performance of a pad-fan evaporative cooling system can be determined by numerous researchers, Liao and ASAE (2000), Chiu (2002), and Teitel et al. (2003), as follows: 1- Weather conditions. 2- Pad material. 3- Pad thickness and density. 4- Pad faces air velocity. 5- Water flow in pads. They also showed that evaporative cooling requires water to keep pads wet. Under normal conditions, a swamp cooler can use between 3 to 15 gallons of water a day, depend on the size of the swamp cooler and whether. They also showed that a fan draws air through the pads, where evaporation drops the temperature approximately 20 degrees ${ }^{\circ} \mathrm{C}$ in just seconds. Meanwhile, Kader (1992), Wang (1993), Wilson et al. (1995), and Hugh (2008) showed that in designing aspen pad coolers mounted vertically (5 - $10 \mathrm{~cm}$ thick), the adequate efficiency can be achieved with good distribution of water at flow rate about $2.4 \mathrm{~L} / \mathrm{min} . \mathrm{m}^{2}$ of pad surface. They also added that evaporative cooler can be combined with a forced air cooler for small lots of produce. Air is cooled by passing through the wet pad before it passes through the packages and around the produce. The air can be cooled to within a few degrees of the wet bulb temperature of ambient air.

In recent years, increasing interest has been focused on the possibility of using some local materials such as rice straw and palm leaf fibers to replace the imported pads. Darwish (2006) found that temperature reduction for all rice straw treatments was higher than that for palm leaf fibers. It ranges from 5.67 to $8.66{ }^{\circ} \mathrm{C}$ for all rice straw treatments, while, in it ranged from 5.01 to $7.50{ }^{\circ} \mathrm{C}$ for all palm leaf treatments. Whilst, Ashour (1997) concluded that the maximum efficiency of evaporative pad cooling were obtained at density $50 \mathrm{~kg} / \mathrm{m}^{3} 10 \mathrm{~cm}$ rice straw pad thickness. Basiouny and Abdallah (2008) showed that the highest average cooled air temperature was found at rice straw pad thickness of $15 \mathrm{~cm}$ and pad-face air velocity of $1.0 \mathrm{~m} / \mathrm{s}$.

In Egypt, there are lots of refrigerated storages used for storage of fruits and vegetables. Any method of increasing the relative humidity of the storage environment will slow the rate of water loss. Dumping water on the floor is a simplest method to add moisture to the air. However, wetting the floor is not a good plant sanitation procedure because it also wets hidden and hard to reach places where disease organisms can grow. 
Modify and improve of an existing refrigerated storage room's to include evaporative cooling unit to overcome problems associated with irregular relative humidity, may help farmers and market dealers to maintain the quality of produce with accurate way. The cheapness and simplicity of this modification would encourage the farmers to use it on a national scale. The main objectives of this research work were to:

1. Test and evaluate the possibility of using the evaporative cooler to control air relative humidity inside storage room's and recommending specific improvements based on the results.

2. Study the effect of some operating parameters such as, water flow rate of pad surface and pads face air velocity on the air temperature and relative humidity.

3. Study the effect of such process on the performance of cold storage rooms in terms of tomatoes fruits storageability (weight loss percentage) and fruits firmness were also considered.

\section{EXPERIMENTAL PROCEDURE AND MEASURMENTS}

To perform the objectives of this study, a small scale cold storage was used and tested in the pilot plant of the Rice Mechanization Center (RMC) of Ag. Eng. Res. Institute (AEnRI), in Meet El-Dyba, Kafr ElSheik Governorate. This type of refrigerated storage were prevalence in our Egyptian villages, and generally used for short or long-term storage of fruits and vegetables.

The experimental work was divided into two stages. First stage was employed to design, built, and test a small evaporative cooler to assess its cooling efficiency under different parameters such water flow rate of pad surface and pads face air velocity. Based on the previous assessment, a digital humidifier was equipped with cooler to adjust the relative humidity as desired. Second stage was devoted to test, examine and compare the performance of storage room before and after modification. Comparison was based on the storageability of tomatoes (weight loss percentage) and fruits firmness.

\section{The Experimental Cold Storage:}

A full insulated refrigeration chamber accompanied with a 4 tons refrigeration unit model MITSUBISHI (R.F-310) was used for cold storage method. The dimensions of the refrigerated chamber were $3.2 \mathrm{~m}$ 
long, $2.6 \mathrm{~m}$ wide and $3.7 \mathrm{~m}$ high with a full floor area of $8.32 \mathrm{~m}^{2}$. The chamber arranged with metal shelves to accommodate the product containers. The experimental storage unit was modified by adding a small evaporative cooler located on a shelf near the ceiling to humidify the air inside the storage chamber.

\section{- Evaporative Cooler.}

Two centrifugal fans $\left(2.0 \mathrm{~m}^{3} / \mathrm{s}\right.$ discharges $)$ rotating in a volute casing was used for forced-air cooling. The blowers powered directly by a single phase electric motor $0.75 \mathrm{hp}$ with a rotating speed of $1440 \mathrm{rpm}$. A blower and duct for forcing air were located at one side of the pads, to force dry air stream through the wetted pads and blows the new cooled air throughout the storage as illustrated in (Fig. 1). Pad face air velocities were varied by changing the fan air flow rate by using an electric switch having certain ability for varying the rpm of the fan. Air speed exiting at the fan outlet was determined as the mean value of the four measured values.

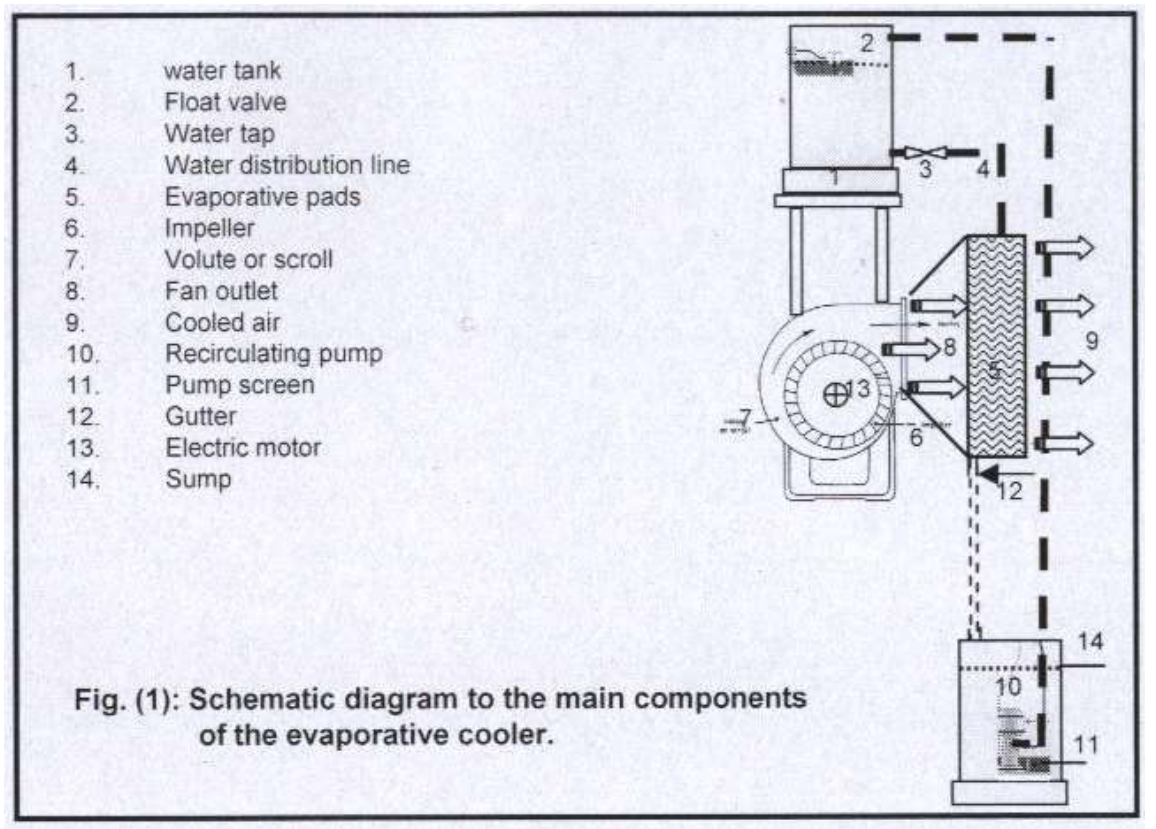

A vertical pad $(30 \times 100 \mathrm{~cm})$ were fabricated manually by filling uniformly the rice straw pad material in a wire net at a specific pad thickness $(10 \mathrm{~cm})$ to provide a constant pad density of about $50 \mathrm{~kg} / \mathrm{m}^{3}$ according to, Ashour (1997). The prepared pad was constructed and fixed 
in a steel frame equipped with steel screen and has the capability of matching with the pad thickness by means of screw bolts.

Water distribution system (Fig. 1) consists of a water tank, water control valve (tap) and perforated water pipe was used to uniformly distribute water over the pad. The water tank is filled by a connection with a domestic tap. Water passed from the tank through a water control valve to the perforated pipe and falls upon the pad. Excessive water was received in a gutter located below the pad. A small recirculating water pump sends the collected water back to the top of the water tank. Since water is continually lost through evaporation, a float valve - much like the one that controls the water in a toilet tank - adds water to the sump when the level gets low. A digital humidifier was equipped with cooler to adjust the relative humidity inside the storage room as desired.

\section{- Treatments and Storage Conditions:}

The main variables taken in this evaluation stage were selected according the relevant studies as recommended by Wang (1993) and Kader (1992) as follows:

- Four different water flow rate of pad surface $(0.075,0.120,0.165$ and $0.210 \mathrm{~m}^{3} / \mathrm{h}$ ).

- Three different pads face air velocity $(0.25,0.50$ and $0.75 \mathrm{~m} / \mathrm{s})$.

Tests were conducted to cover the full combinations of the considered variables under their different levels on the air temperature, and relative humidity inside storage room.

Quality characteristics of the stored tomatoes in terms of tomatoes fruit firmness and tomatoes storageablity were also considered to evaluate the cold storage room performance. During storage period tomatoes fruits were stored at $20{ }^{\circ} \mathrm{C}$ and $80-90 \% \mathrm{RH}$ for 3 weeks, according to, (Lisa and Kader, 2004) and (Janet and Richard, 2000).

\section{- Procedures and Measurements:}

- Tomatoes fruits variety Castelrock at pink ripening stage was used in this study. After manual harvest, tomatoes were inspected for damage and sorting out good tomatoes from the lot as picked from the field by manual picking. Then, the fruits were packed in plastic mesh baskets, and transported from the field to the storage room within 2 hours. Two parts of tomatoes fruits were used: 
- The first part of tomatoes was placed on the cooling chamber after modified by adding a small evaporative cooler to humidify the air inside the storage chamber. The samples were stored at cooling chamber under the desired conditions of temperature $\left(20 \pm 1{ }^{\circ} \mathrm{C}\right)$ and relative humidity level (80-90\%) for 3 weeks, according to Lisa and Kader (2004) and Janet and Richard (2000). The second part of tomatoes (control treatment) was stored at cooling chamber without modification, for 3 weeks.

During the experimental work, ambient air temperature and air relative humidity were daily measured by using a hand-held, digital readout, hot wire thermometer and anemometer, model Testo-425, Germany, with accuracy of $\left( \pm 0.1^{\circ} \mathrm{C}\right)$, and $( \pm 0.01 \mathrm{~m} / \mathrm{s})$. While tomatoes losses and quality change during storage were measured every week.

\section{- Measurements of cooled air temperature and relative humidity.}

To assess and evaluate the storage performance, the distributions of air temperature and relative humidity inside the storage chamber was measured and recorded. Twenty seven thermocouples (copper constantan) were used and evenly distributed in three parallel planes at different heights inside the storage room at the bottom, middle and top of the chamber in order to measure the air temperature.

\section{- Pad faces air velocity.}

Pad face air velocities were varied by changing the fan air flow rate by using an electric switch having certain ability for varying the rpm of the fan. Air speed exiting at the fan outlet was determined as the mean value of the four measured values.

\section{- Evaluation of cold storage room performance:}

Cold storage room performance in terms of tomatoes fruits storageability (total weight loss percentage) and fruits firmness were also considered.

\section{- Firmness of tomato fruits.}

Tomatoes Castelrock variety was harvested at pink ripening stage and fruit firmness was measured initially for this stage, and followed after 3 week of a storage period.

Digital penetration meter (model FGC-50) was used with accuracy of 0.1 Newton, a single fruit was pressed by the conical end of the appropriate plunger with diameter $0.8 \mathrm{~mm}$. The digital reading was increased with the increasing of the pressure on the fruit until the fruit 
has been cracked. At this point the recorded digital reading (Peak) is the fruit hardness. Only one reading was recorded of each tomato fruit sample.

\section{- Storability of tomato fruits (total loss in weight).}

After storage process, storage-ability was measured as percentage of total loss in weight of tomatoes during a storage period of 3 weeks. Total losses were determined by examining the yield every week, and then the total storage losses were then estimated.

\section{RESULTS AND DISCUSSION}

\section{- Cooling Room Performance Without Evaporative Cooler.}

Figure (2) illustrates the hourly average variation of cooled air temperature and relative humidity inside the storage room before modification as affected by daytime. As shown in Fig. (2) the minimum cooled air temperature and the maximum relative humidity were found at nine o'clock. The averaged values of both cooled air temperature and relative humidity were $22.42{ }^{\circ} \mathrm{C}$ and $60.82 \%$ respectively (Table, 1).

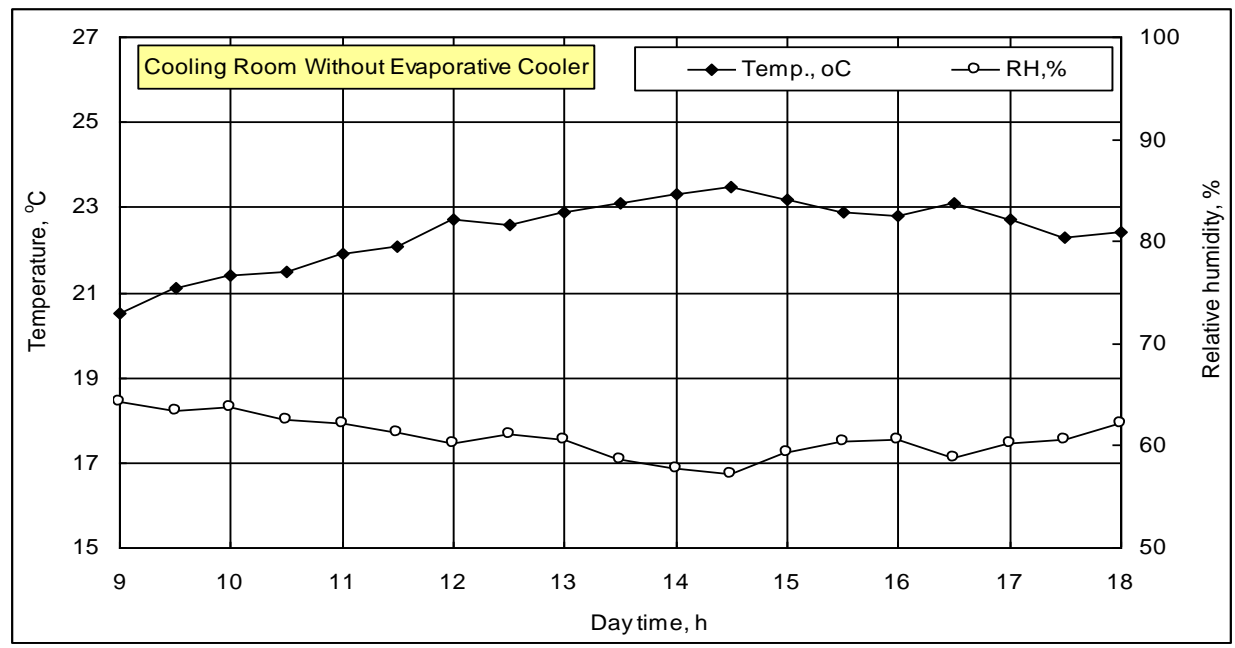

Fig. (2): Hourly average variations of cooled air temperature and relative humidity inside the storage room before modification as affected by daytime.

\section{- Cooling Room Performance With Evaporative Cooler.}

Table (1) indicates the averaged values for both cooled air temperature and relative humidity. At the same time, the values of standard deviation was calculated and listed in Table (1) at different water flow rates of pad, 
and pad face air velocities. In general, at any pad-face air velocity from 0.25 to $0.75 \mathrm{~m} / \mathrm{s}$ the highest mean value of relative humidity were achieved at $0.165 \mathrm{~m}^{3} / \mathrm{h}$ water flow rate comparing with the other water flow rates of pads. The data reveled that the highest mean value of air relative humidity $\left(88.46 \%\right.$ ) was obtained at $0.165 \mathrm{~m}^{3} / \mathrm{h}$ and $0.5 \mathrm{~m} / \mathrm{s}$. Whilst, the lowest mean value of $65.33 \%$ relative humidity was obtained at $0.075 \mathrm{~m}^{3} / \mathrm{h}$ and $0.25 \mathrm{~m} / \mathrm{s}$ as shown in Table (1). The difference between the highest and lowest mean values of air relative humidity could be estimated by $35.40 \%$ increment. The minimum mean value of cooled air temperature $\left(19.1^{\circ} \mathrm{C}\right)$ was obtained at $0.165 \mathrm{~m}^{3} / \mathrm{h}$ and $0.5 \mathrm{~m} / \mathrm{s}$. Whilst, the maximum mean value of cooled air temperature $\left(21.5^{\circ} \mathrm{C}\right)$ was obtained at $0.075 \mathrm{~m}^{3} / \mathrm{h}$ and $0.25 \mathrm{~m} / \mathrm{s}$ as shown in Table (1).

It may be concluded that, the average cooled air temperature for the cooled room with evaporative cooler was less than that without evaporative cooler. On the other hand, the average values of relative humidity in the cooled room with evaporative cooler were higher than that without evaporative cooler.

Table (1): Average cooled air temperature and relative humidity at different water flow rates of pad and pad-face air velocities.

\begin{tabular}{|l|c|c|c|c|c|c|c|c|c|c|c|c|}
\hline \multicolumn{10}{|c|}{ Cooled room after modification (with evaporative cooler). } \\
\hline Water flow rate of pad, $\mathrm{m}^{3} / \mathrm{h}$ & \multicolumn{3}{|c|}{0.075} & \multicolumn{3}{c|}{0.120} & \multicolumn{3}{c|}{0.165} & \multicolumn{3}{c|}{0.210} \\
\hline pad-face air velocity, $\mathrm{m} / \mathrm{s}$ & 0.25 & 0.50 & 0.75 & 0.25 & 0.50 & 0.75 & 0.25 & 0.50 & 0.75 & 0.25 & 0.50 & 0.75 \\
\hline Mean cooled air temperature, ${ }^{\circ} \mathrm{C}$ & 21.5 & 21.20 & 21.30 & 20.8 & 20.5 & 20.60 & 19.70 & 19.10 & 19.40 & 20.40 & 19.90 & 20.30 \\
\hline SD., of cooled air temp., ${ }^{\circ} \mathrm{C}$ & 0.65 & 0.91 & 0.59 & 0.721 & 0.67 & 0.811 & 0.52 & 0.78 & 0.44 & 0.57 & 0.90 & 0.78 \\
\hline Mean relative humidity (RH), $\%$ & 65.33 & 71.56 & 69.25 & 77.86 & 81.23 & 78.11 & 83.19 & 88.46 & 84.05 & 79.11 & 82.67 & 80.87 \\
\hline SD., of RH, \% & 2.12 & 3.66 & 3.03 & 2.952 & 1.09 & 1.99 & 1.005 & 0.94 & 1.07 & 1.77 & 1.42 & 2.33 \\
\hline
\end{tabular}

Figure (3) shows the hourly average variation of cooled air temperature and relative humidity as affected by daytime at different water flow rates of pads and pad-face air velocity at $0.5 \mathrm{~m} / \mathrm{s}$.

As shown in Fig. (3), the lowest value of cooled air temperature $\left(17.4{ }^{\circ} \mathrm{C}\right)$ was obtained at water flow rate of pad $\left(0.165 \mathrm{~m}^{3} / \mathrm{h}\right)$ at nine o'clock. Meanwhile, the highest value of relative humidity (89.9\%) was obtained at the same conditions of water flow rate of pad $\left(0.165 \mathrm{~m}^{3} / \mathrm{h}\right)$ and padface air velocity $(0.5 \mathrm{~m} / \mathrm{s})$. 


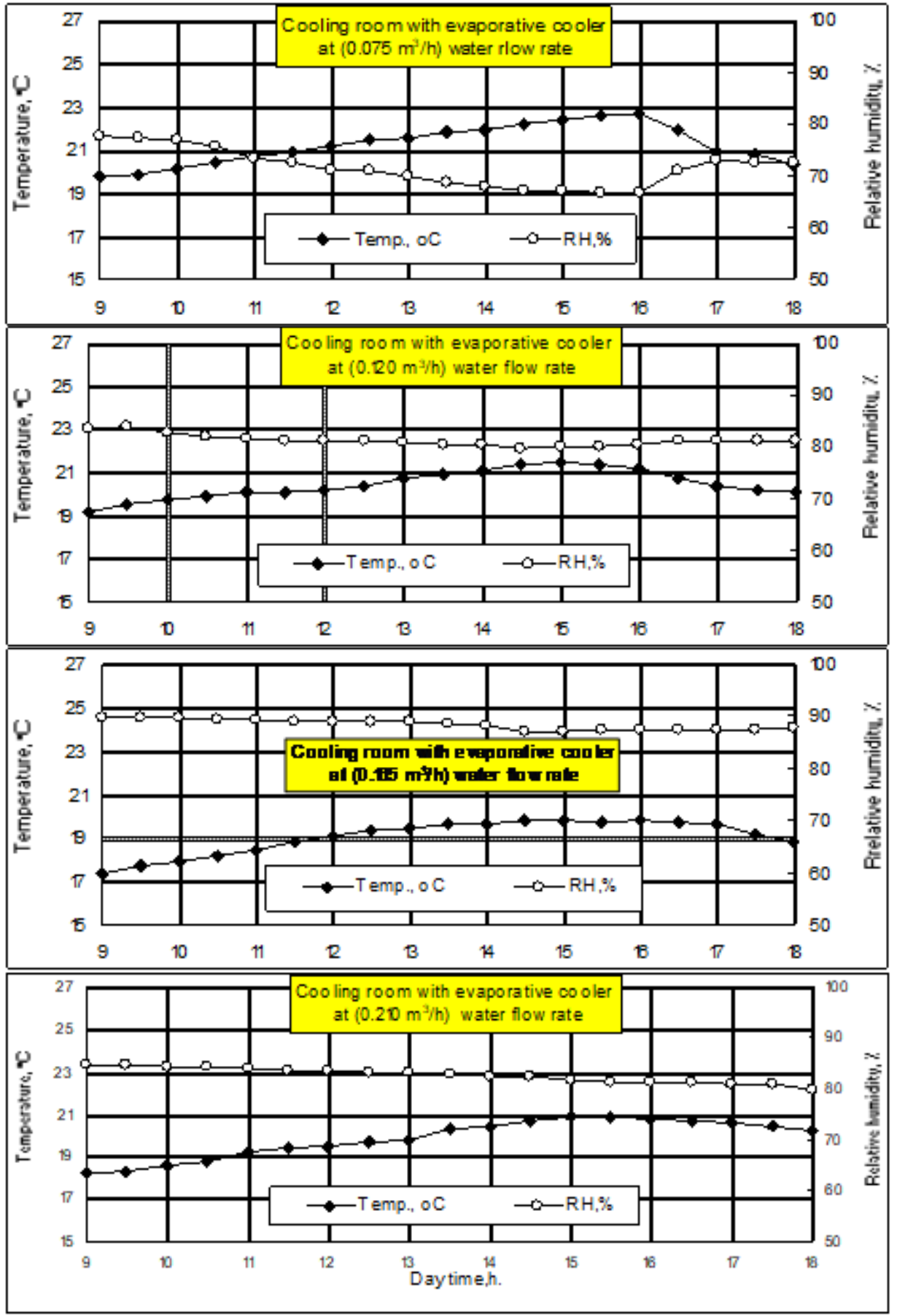

Fig. 3: Hourly average variations of cooled air temperature and relative humidity as affected by daytime at different water flow rates of pads and $(0.5 \mathrm{~m} / \mathrm{s})$ pad-face air velocity .

The $16^{\text {th }}$. Annual Conference of the Misr Society of Ag. Eng., 25 July, 20091641 


\section{- Quality Characteristics As Affected By Storage Room Performance.}

The quality characteristics of the stored tomatoes in terms of storageablity (total weight loss percentage) and tomatoes firmness were also considered to evaluate the cooled storage room performance.

\section{- Storageability of tomatoes fruits.}

The aforementioned result showed that, the best ever result was obtained at $0.165 \mathrm{~m}^{3} / \mathrm{h}$ of water flow rates of pad and $0.5 \mathrm{~m} / \mathrm{s}$ of pad-face air velocity. At these levels maximum relative humidity $(88.46 \%)$ and acceptable value of cooled air temperature $\left(19.1{ }^{\circ} \mathrm{C}\right)$ were obtained, hence, the quality evaluation tests were carried out under these treatments.

Storability was measured as a total loss in weight of tomatoes during a storage period of 3 weeks. After storage period before modification (control treatment), the quality that assessed as weight of total loss during a storage period of 3 weeks was markedly increased which was $14.69 \%$.

Meanwhile, storability of tomatoes fruits was highly improved with increasing air relative humidity to $89.9 \%$. The maximum deteriorated of tomatoes $(5.62 \%)$, comparing with the deteriorated value of control treatment $(14.69 \%)$. This increase in the total loss of tomatoes before modification may be due to the direct effect of storage air temperature and relative humidity on the respiration rate of plant tissue that generates heat as sugars, fats, and proteins in the cells of the crop are oxidized. Which in turn increases the damaged cells of plant, and that led to increase the total losses (storability) of tomato fruits (Table, 2). On other words, the relative humidity of the storage room directly influences water loss in produce these loss means decreased food value, loss of flavor, loss of salable weight, and more rapid deterioration.

\section{- Firmness of tomato fruits.}

Tomatoes Castelrock variety was harvested at pink ripening stage and fruits firmness was measured initially before storage and after three week of a storage period. Data in Table (2) showed the Average firmness of tomato fruits as affected by cooled storage room before and after modification (with evaporator cooler). The initial fruit firmness was 65.42 $\mathrm{N}$ for pink stage. In general, the fruit firmness of all tomatoes samples declined during storage but the declination was highly dependent on the 
storage room conditions.

After storage period the highest firmness value $(59.84 \mathrm{~N})$ was obtained when using evaporator cooler with cooled storage. Meanwhile, tomatoes stored without evaporator cooler gave the lowest firmness $(48.66 \mathrm{~N})$, which was coupled with maximum total damage $(14.69 \%)$. This decrease in fruit firmness stored without evaporator cooler may be due to the direct effect of water losses from plant tissues and increasing the transpiration rate as result of storage in unfavorable ambient conditions of temperature and relative humidity, which increase respiration rate and generates heat as sugars, fats, and proteins in the cells of the crop are oxidized that decrease the total soluble solid in the fruits which in turn, decrease fruits firmness.

Table (2): Storageability and firmness of tomatoes fruits as affected by cooled storage room conditions before and after modification

\begin{tabular}{|c|c|c|c|c|}
\hline \multirow{2}{*}{ Storage Conditions } & \multicolumn{4}{|c|}{ Characteristics } \\
\cline { 2 - 5 } & $\begin{array}{c}\text { Storageability } \\
\text { (Total loss, \%) }\end{array}$ & $\begin{array}{c}\text { Before } \\
\text { storage period }\end{array}$ & $\begin{array}{c}\text { After storage } \\
\text { period }\end{array}$ & $\begin{array}{c}\text { Frmness } \\
\text { loss, \% }\end{array}$ \\
\cline { 3 - 5 } & 14.69 & 65.42 & 48.66 & 25.62 \\
$\begin{array}{c}\text { Cooling room without } \\
\text { evaporative cooler } \\
\text { (Before modification) }\end{array}$ & 7.62 & & 59.84 & 8.52 \\
\hline $\begin{array}{c}\text { Cooling room with } \\
\text { evaporative cooler } \\
\text { (After modification) }\end{array}$ & & & & \\
\hline
\end{tabular}

* Tomatoes fruits were stored under conditions of $20{ }^{\circ} \mathrm{C}$ and $80-90 \% \mathrm{RH}$.

\section{CONCLUSION}

- The best ever result was obtained at $0.165 \mathrm{~m}^{3} / \mathrm{h}$ of water flow rates of pad and $0.5 \mathrm{~m} / \mathrm{s}$ of pad-face air velocity. At these levels maximum relative humidity $(88.46 \%)$ and acceptable value of cooled air temperature $\left(19.1{ }^{\circ} \mathrm{C}\right)$ were obtained.

- Before modification (control treatment), the quality that assessed as weight of total loss during a storage period of 3 weeks was markedly increased which was $14.69 \%$.

- Storability of tomatoes fruits was highly improved by increasing air relative humidity to $89.9 \%$. The minimum deteriorated of tomatoes The $16^{\text {th }}$. Annual Conference of the Misr Society of Ag. Eng., 25 July, 20091643 
(5.62\%) was obtained when tomatoes stored with evaporator cooler, comparing with the deteriorated value of control treatment (14.69\%).

- Tomatoes stored without evaporator cooler gave the lowest firmness $(48.66 \mathrm{~N})$, which was coupled with maximum total damage $(14.69 \%)$.

\section{REFERENCES}

ASAE Standards. 2000. Structures Livestock and Environment.Livestock Ventilation System Performance. ASAE Standards 2000.

Ashour, T. H. M. A. (1997). Environmental studies for broiler houses of kaluobia governorate. M Sc. thesis. Agronomy and Ag. Mech. Dept, Fac. of Ag. Moshtohor, Zagazig Univ., Benha Branch., Egypt.

ASHRAE (1998). Evaporative Air Cooling. The ASHRAE Handbook, the American Society of Heating, Refrigerating and Air-Conditioning Engineers, Inc. Millstar Electronic Publishing. CHAPTER 47.

Basiouny, M. A. and S. E. Abdallah (2008). Influence of pad configuration on evaporative cooling system effectiveness inside a wind tunnel. The $15^{\text {th }}$ Annual Conf. of the Misr Society of Ag. Eng., 12-13 march, 2008: 591-613.

Byczynski, Lynn. 1997. Storage crops extend the season. Growing for Market. Sep. p. 1, 4-5.

Campos, A. T., E. S. Kolosowski and E. Gasparino (2002). Study of the air temperature reduction potential through the evaporative cooling system in the region of Maringa- PR Brazil. Acta Sci., 24 (5): 15751581 (abstract).

CEC - California Energy Commission (2006). Evaporative Cooling. Consumer Energy Center. Copyright California Energy Commission. Evaporative Cooling.mht.

Darwish, M. R. (2006). Environmental control inside an agricultural structure. performance criteria of two evaporative cooling pads made of agricultural residues to reduce heat stress inside agricultural structure. Unpubl. M. Sc. thesis. Ag. Mech. Dept, Fac. of Ag., Kafr El-Sheikh, Tanta Univ., Egypt.

Geeson,D. J. (1989). cooling and storage of fruits and vegetables. In proceeding of the institute of Refrigeration, Vol. 85, pp. 65-76.

Hugh W. Fraser (2008). Tunnel Forced-Air Coolers for Fresh Fruits \& Vegetables. Ontario Ministry of Ag., Food and Rural Affairs 
(OMAFRA). Canda.

James, F. T (1996). Perishables handling newsletter. Forced air cooling. Univ. of Callifornia, issue No. 88. pp. 7.

Janet, B., and Richard, E. (2000). Postharvest Handling of Fruits and Vegetables. (ATTRA) Appropriate Technology Transfer for Rural Areas. the national sustainable agriculture information center USDA's Rural Business - Cooperative Service.

Kader, A. A. (1992). Postharvest Technology of Horticultural Crops. University of California, Division of Agriculture and Natural Resources, Publication 3311. 296 pp.

Leon, J. C.; B. Babin and C. Y. Choi (1998). Design, construction, and evaluation of a compact recalculating wind tunnel for agricultural experiments. Trans. of the ASAE, 41(1): 213-218.

Liao, C. m. and K. h. Chiu (2002). wind tunnel modling the system performance of alternative cooling pads in taiwan region. Buliding and environment, No. 37, pp 177-187.

Lisa, K. and , A.A. Kader (2004). Postharvest horticultural series No. 8. Small-Scale Postharvest Handling Practices: A Manual for Horticultural Crops (4th Edition). University of California - Davis.

Tassou, S. A., and W. Xiang (1998). Modling the invironment within a wet air cooled vegetable store. J. oF Food Engineering 38,pp. 169187.

Teitel,m., M. Barak and Y.Zhao (2003). Tempreature and humidity gradients in fan ventilated greenhouses under two cooling modes. Acta Horticulture, No. 614 (2): 469-475.

USDE - U.S. Department of Energy (2009). Energy efficiency and renewable energy. Energy savers evaporative coolers.mht. http://www.USA. energy gov.

Wang, S.k. (1993). Evaborative cooling and evaporative coolers. Hand book of air conditioning and refrigeration. Ch. 13.

Wikipedia ${ }^{\circledR}$ (2009). Evaporative coolers. Wikipedia, the free encyclopedia.mht. http://www.wikimediafoundation. org.

Wilson, L.G., M.D. Boyette, and E.A. Estes. 1995. Postharvest Handling and Cooling of Fresh Fruits, Vegetables and Flowers for Small Farms. Leaflets 800-804. North Carolina Cooperative Extension 
Service.

p.

Accessed

on-line

at:

http://www.foodsafety.org/nc/nc1055.htm

\section{تحسين أداء غرف تلخزين الخضي الخضار المبردة

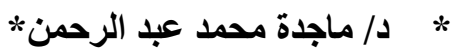

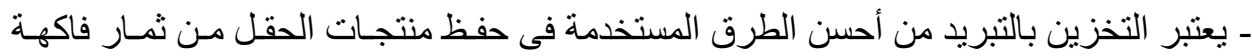

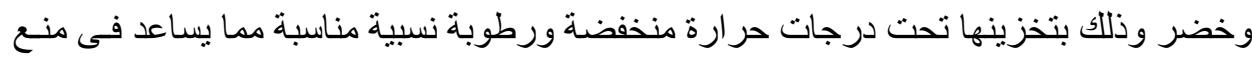

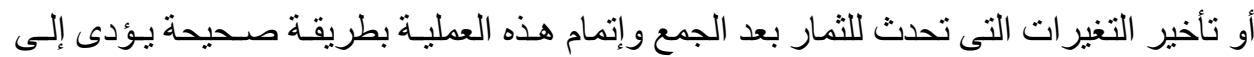

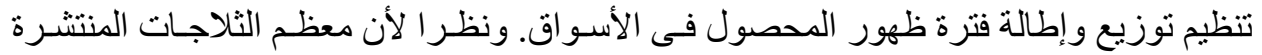

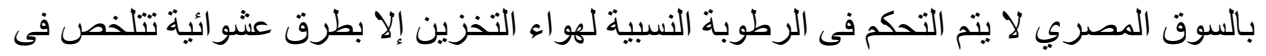

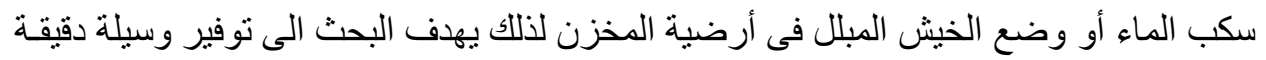

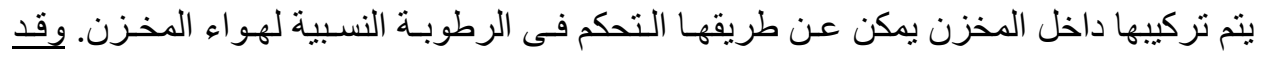
انتملت الدر اسة على مرحلتين:• المرحلة الأولي: تم تنفيذها بهدف تصنيع وتطوير وتقييم مبرد تبخيري من النوع ذو الوسادة

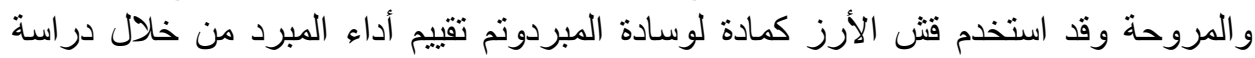

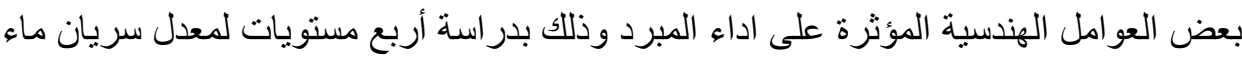

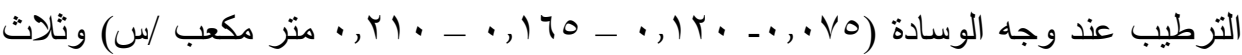

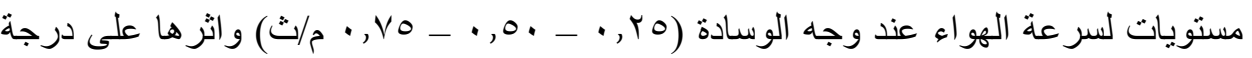

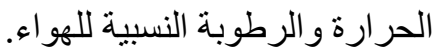
• المرحلة الثانية: تم تتفيذها بهدف مقارنة أداء غرفة التخزين المبرد قبل وبعد نركيب وحدة التبريد التبخيرى المقترحة. وتم تقييم اداء غرفة التخزين باستخدام محصول الطماطم من خلال تقدير النسبة المئوية للفقد الكلى في الثمار المخزنة (قابلية ثمار الطماطم للتخزين) وتقدير درجة صلابة الثمار المخزنة. وفيما يلي ملخص لأهم النتائج :

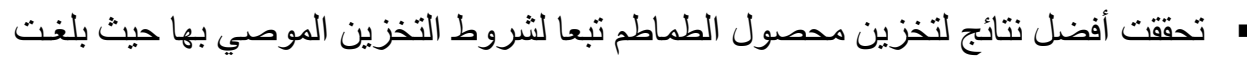

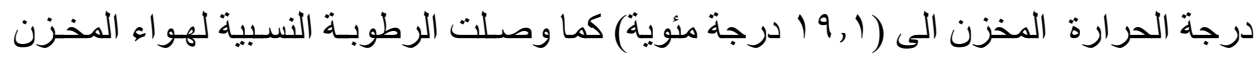

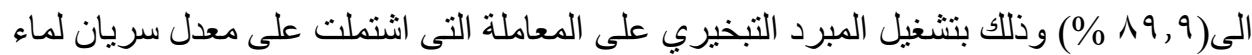

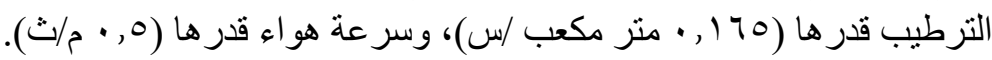

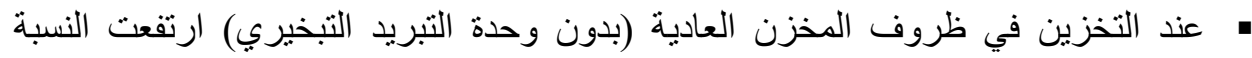
المئوية للفقد الكلى في الثمار المخزنة (انخفضت قابلية ثمار الطماطم للتخزين) حيث كانت التهان

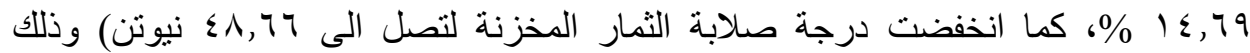

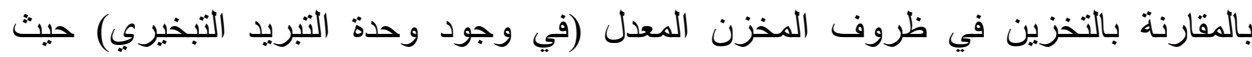
انخفضت النسبة المئوية للفقد الكلى في الثمار المخزنة (زادت قابلية ثمار الطماطم للتنزين)

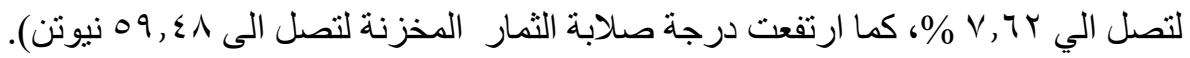

* باحث أول بمعهد بحوث الهندسة الزر اعية ـ الدقي - جيزة. 